\title{
BAX pro-apoptotic gene alterations in repeated pregnancy loss
}

Seyed Mohammad Seyedhassani ${ }^{1,2}$, Massoud Houshmand ${ }^{2}$, Seyed Mehdi Kalantar ${ }^{1}$, Abbas Aflatooniann', Glayol Modabber², Feyzollah Hashemi-Gorji', Zahra Hadipour ${ }^{3}$

${ }^{1}$ Research and Clinical Center for Infertility, Shahid Sadoughi University of Medical Sciences, Yazd, Iran

2Department of Medical Genetics, National Institut of Genetic Engineering and Biotechnology, Tehran, Iran

3Special Medical Center, Tehran, Iran

Submitted: 18 April 2010

Accepted: 18 August 2010

Arch Med Sci 2011; 7, 1: 117-122

DOI: $10.5114 /$ aoms.2011.20614

Copyright @ 2011 Termedia \& Banach

\section{Abstract}

Introduction: Recurrent pregnancy loss (RPL) is a critical medical problem in about $0.5-2 \%$ of women. The molecular genetic background for spontaneous abortion is being increasingly understood, and some polymorphisms associated with it have been reported. This study investigates alterations of the Bax gene as a pro-apoptotic gene in women with idiopathic RPL.

Material and methods: The frequency of mutations in the Bax gene of 67 idiopathic RPL women was studied in comparison to a sample of 70 healthy women. The promoter and the entire coding regions (exons 1-7) were amplified using polymerase chain reaction (PCR). The purity of the PCR product was first verified by electrophoresis on a $2 \%$ agarose gel. The amplified fragment was then sequenced by automated DNA sequencing.

Results: A statistically significant difference was observed between patients and the control group regarding the frequency of alleles $A(-179) G$ in the Bax promoter region $(p=0.013)$. Also among patients, G90C and G95A transitions were found in the coding region of exon 1 that change amino acid glutamine $(\mathrm{Q})$ to histidine $(\mathrm{H})$ and arginine $(\mathrm{R})$ to lysine $(\mathrm{K})$, respectively. A statistically significant association was observed between $\mathrm{H}$ allele $(p=0.0001)$ and $\mathrm{K}$ allele $(p<0.0001)$ and the occurrence of RPL.

Conclusions: Our results indicate an association between A(-179)G mutation in the Bax promoter and RPL. Moreover, two polymorphisms, G90C and G95A in exon 1, found among our patients, could be considered as genetic factors making people susceptible to miscarriages. According to our findings, the Bax gene has an important role in pregnancy loss and the variations of this gene could help in the assessment of RPL.

Key words: BAX, repeated pregnancy loss, polymorphism, apoptosis.

\section{Introduction}

Pregnancy loss is the most common complication in pregnancies and is defined as the unexpected and unplanned spontaneous loss of a pregnancy before the fetus is competent for extrauterine survival. Clinically recognized pregnancies terminate as a miscarriage in about $15 \%$ of cases [1]. Traditionally, recurrent abortion has been defined as the occurrence of three or more clinically recognized pregnancy losses before

\author{
Corresponding author: \\ Massoud Houshmand, PhD \\ Department of Medical \\ Genetics \\ National Institute of Genetic \\ Engineering and \\ Biotechnology \\ Pajoohesh Blvd. \\ Tehran-Karaj Highway, $17^{\text {th }} \mathrm{km}$ \\ PO Box 14155-6343 \\ Tehran, Iran \\ Phone: +982144580390 \\ Fax: +98 2144580399 \\ E-mail: massoudh@nigeb.ac.ir
}


20 weeks from the last menstrual period. About 1 in 300 couples and $0.5-2 \%$ of women are affected by repeated pregnancy loss (RPL) [2]. Assumed aetiological factors are chromosomal aberrations, uterine abnormalities, infectious disorders and endocrine dysfunctions such as hypothyroidism and luteal phase deficiency. These factors are present in about $50 \%$ of all women with RPL, but in the majority of cases the cause is unknown or idiopathic [3, 4]. For idiopathic RPL, recent studies propose that polymorphisms are susceptibility factors, which increase the chance of miscarriage [5-13].

In fact, biological processes supporting normal pregnancy are mediated by a series of differential gene expressions that can be affected by genomic variations. The pattern of fragmentation is one of these processes, and is a major predictor for developmental potential [14]. While some patterns of fragmentation have been ascribed to a process of oncogenesis [15], a series of experiments also suggested that a subset of embryo fragmentations results from apoptotic-like disintegration [16]. Human embryos often arrest and undergo fragmentation at the 4-8 cell stage, when the transition is supposed to happen from the maternal to embryonic genome [17].

It is evident that embryo viability depends on alterations in the expression of cell death regulatory molecules, although there are still controversies about apoptosis being a primary or secondary process in cellular fragmentation [16]. This is supported by reports on alteration in the ratio of $\mathrm{BCl}-2$ and Bax protein, as a very important apoptotic related protein, in bovine viable oocytes and embryos [18], as well as the elevated expression of $\mathrm{Bcl}-2$ and Bax during compaction of the human embryo [19]. The modulated expression of Bax mRNA in human viable and non-viable embryos is another observation supporting this hypothesis [20]. The abnormal expression of apoptosis-related genes is seen in RPL [21]. In the internal apoptotic or mitochondrial pathway, one of the major genes of the Bcl-2 family is the Bax gene, which has an important role in fertilization and proliferation of the cells. Bax is a death-promoting protein shown to be a tumour suppressor and provoking cellular apoptosis in vivo [22-24]. Also lower expression of the Bax gene has been observed in some cases of uncontrolled cell proliferation such as breast adenocarcinoma [25]. The Bax gene is located on chromosome 19 and consists of seven exons and a promoter region with four p53 binding sites [26]. Five isoforms of Bax have been documented. In this study, we investigated Bax nucleotide alterations in women with a history of RPL and compared these data with the ones obtained from controls without a history of miscarriage.

\section{Material and methods}

\section{Patients and samples}

A total of 335 couples suffering from RPL were referred to the Research and Clinical Center for Infertility (Iran, Yazd) between September 2006 and June 2008. Among these people, 67 women were screened as idiopathic at reproductive age. Diagnosis of RPL was based on a documented history of at least three consecutive spontaneous abortions before 20 weeks of gestation with the same partner. In this study pregnancy loss was confirmed mainly by observing the empty sac. The aborted material was also examined by the pathologist from some other aspects. Neither these examinations nor the gynaecologist's referral documents reported any case of hydatidiform moles. RPL women underwent a standard diagnostic work-up to rule out any known cause of RPL. The diagnostic procedure included paternal and maternal karyotype, uterine sonography, TORCH infection study (Toxoplasmosis, Rubella, Cytomegalovirus, Herpes Simplex Virus type II and Listeria), assessment of hormonal status, and IgM/lgG anticardiolipin, antiphospholipid tests. All of the cases were suffering from primary RPL and had no history of child delivery. The control group consisted of 70 women with at least two live births and no history of pregnancy loss. All the controls were at reproductive age and underwent sampling in the labour room during their second or later normal delivery. All of the participants were informed about research and signed the consent form approved by the ethical committee.

\section{DNA extraction}

Blood was collected from the women with RPL and the control individuals in tubes containing potassium-EDTA. Genomic DNA was isolated from the blood samples using a Flexigene blood DNA kit (QIAGEN, Germany) according to the manufacturer's protocol. The isolated DNA was stored at $4^{\circ} \mathrm{C}$ until use.

\section{PCR/Sequencing analysis}

Four pairs of primers were designed using the 5' and 3' flanking sequences to amplify the promoter region and the exons of the Bax gene (Table I).

The PCR reactions were performed in four series according to the conditions detailed in Table II. The reaction mixture for $P C R$ contained $10 \mathrm{pM}$ of each primer, 1 unit of Taq polymerase (Cinnagene, Iran), each dNTP at a final concentration of $200 \mu \mathrm{M}$, and $2.5 \mu \mathrm{l}$ PCR buffer at a final volume of $25 \mu \mathrm{l} .1 .5 \mu \mathrm{l}$ of DMSO was also used in the reaction mixture for the promoter and exon 1 fragment. 
Table I. Oligonucleotide primers used in the mutational screening of BAX gene

\begin{tabular}{|lccc|}
\hline Name of primers & \multicolumn{1}{c}{ Sequence } & Tm & Product size [bp] \\
\hline BAX-PE1-F & 5'-CGG GGT TAT CTC TTG GGC-3' & 58.2 & 663 \\
\hline BAX-PE1-R & 5'-TGC TTG GAG ATC GCA CAG-3' & 56.0 & \multirow{2}{*}{811} \\
\hline BAX-E2,3,4-F & 5'-TCT TCC CTT CCT TTC TCC-3' & 53.7 & \\
\hline BAX-E2,3,4-R & 5'-ACC TTG AGC ACC AGT TTG-3' & 53.7 & 710 \\
\hline BAX-E5,6-F & 5'-GAT TCT TGC TCT ATT GTC C-3' & 52.4 & \\
\hline BAX-E5,6-R & 5'-TGA GGA GTC TCA CCC AAC-3' & 56.0 & 303 \\
\hline BAX-E7-F & 5'-ACT GAT GTC CCT GTC TCC-3' & 56.0 & \\
\hline BAX-E7-R & 5'-GAC TCA GAT GCC GAA GTG-3' & 56.0 & \\
\hline
\end{tabular}

Table II. PCR programs for amplification of promoter and exons regions of BAX gene

\begin{tabular}{|lcccccc|}
\hline Fragments & $\begin{array}{c}\text { Initial } \\
\text { denaturation }\end{array}$ & $\begin{array}{c}\text { Number } \\
\text { of cycles }\end{array}$ & Denaturation & Annealing & Extention & $\begin{array}{c}\text { Final } \\
\text { extention }\end{array}$ \\
\hline Promoter and Exone 1 & $95^{\circ} \mathrm{C}-5 \mathrm{~min}$ & 35 & $95^{\circ} \mathrm{C}-1 \mathrm{~min}$ & $55^{\circ} \mathrm{C}-1 \mathrm{~min}$ & $72^{\circ} \mathrm{C}-60 \mathrm{seC}$ & $72^{\circ} \mathrm{C}-5 \mathrm{~min}$ \\
\hline Exone $2,3,4$ & $95^{\circ} \mathrm{C}-5 \mathrm{~min}$ & 35 & $94^{\circ} \mathrm{C}-1 \mathrm{~min}$ & $54^{\circ} \mathrm{C}-1 \mathrm{~min}$ & $72^{\circ} \mathrm{C}-50 \mathrm{seC}$ & $72^{\circ} \mathrm{C}-5 \mathrm{~min}$ \\
\hline Exone 5,6 & $95^{\circ} \mathrm{C}-1 \mathrm{~min}$ & 35 & $94^{\circ} \mathrm{C}-1 \mathrm{~min}$ & $58^{\circ} \mathrm{C}-1 \mathrm{~min}$ & $72^{\circ} \mathrm{C}-50 \mathrm{seC}$ & $72^{\circ} \mathrm{C}-5 \mathrm{~min}$ \\
\hline Exone 7 & $95^{\circ} \mathrm{C}-5 \mathrm{~min}$ & 35 & $94^{\circ} \mathrm{C}-1 \mathrm{~min}$ & $56^{\circ} \mathrm{C}-1 \mathrm{~min}$ & $72^{\circ} \mathrm{C}-30 \mathrm{sec}$ & $72^{\circ} \mathrm{C}-5 \min$ \\
\hline
\end{tabular}

The PCR reactions were performed in a thermal cycler (TECHNE) and the amplified fragments were detected on $2 \%$ agarose gels (Figure 1).

The PCR-amplified fragments were purified and then sequenced by a 3730XL ABI DNA analyzer (Macrogen, Korea). DNA sequences were determined using the same PCR primers. The results of DNA sequence analysis were compared with the published sequences in the NCBI database using the Chromas and Clustal-X programs. Sequence variants not found in the NCBI database were identified as novel alterations.

\section{Statistical analysis}

All statistical analyses were carried out with SPSS software package 16.0 (SPSS Inc., USA). Using Chi-square and Fisher's exact tests, the prevalence of sequence variation was compared between case and control groups. The odds ratio (OR) was used as a measure of the strength of the association between allele frequencies and idiopathic recurrent miscarriage. $P<0.05$ was considered statistically significant.

\section{Results}

Our data show that the mean \pm SD age of the women with RPL at the time of blood sampling was $27.54 \pm 5.08$ and the mean \pm SD number of pregnancy losses in this group was $3.84 \pm 1.62$ (Table III). There was a consanguineous marriage in 27 (40.3\%) women with RPL and 23 (32.9\%) healthy women. The difference between the two groups was not significant $(P=0.366)$.
Sequencing of the Bax gene showed three alterations in the promoter region and exon 1 . The promoter genotype of $67 \mathrm{RPL}$ and 70 healthy women was determined from 400 nucleotides before exon 1. An A(-179)G transition was observed

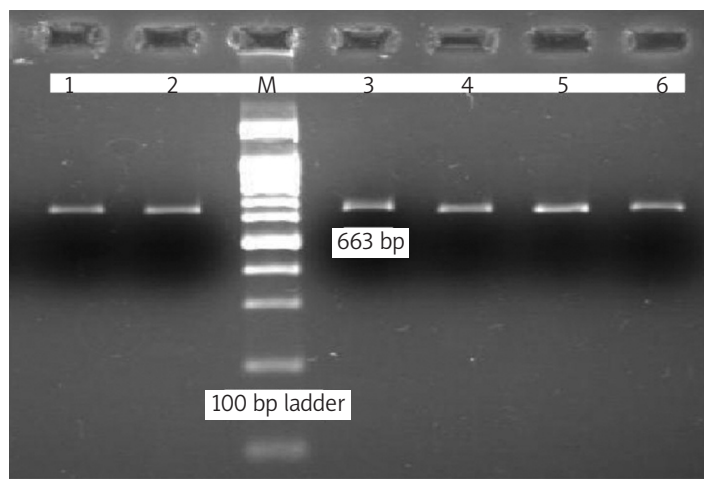

Figure 1. Demonstration of amplified 663-base-pair promoter and exon 1. Lanes 1-6 show the amplified fragment from samples and controls, and $M$ shows the 100-base-pair DNA ladder

Table III. Characteristics of RPL and healthy women

\begin{tabular}{|lcc|}
\hline & RPL women & Healthy women \\
\hline $\begin{array}{l}\text { Mean age } \pm \text { SD } \\
\text { at miscarriage study [years] }\end{array}$ & $27.54 \pm 5.08$ & $30.20 \pm 4.11$ \\
\hline $\begin{array}{l}\text { Age at miscarriage } \\
\text { study [years]* }\end{array}$ & $27(19-40)$ & $30(22-39)$ \\
\hline $\begin{array}{lcc}\text { No. of live birth } \\
\text { No. of miscarriage* }\end{array}$ & $3(3-11)$ & $2(2-4)$ \\
\hline Mean \pm SD of miscarriage & $3.84 \pm 1.62$ & 0 \\
\hline
\end{tabular}

*Median (range) 

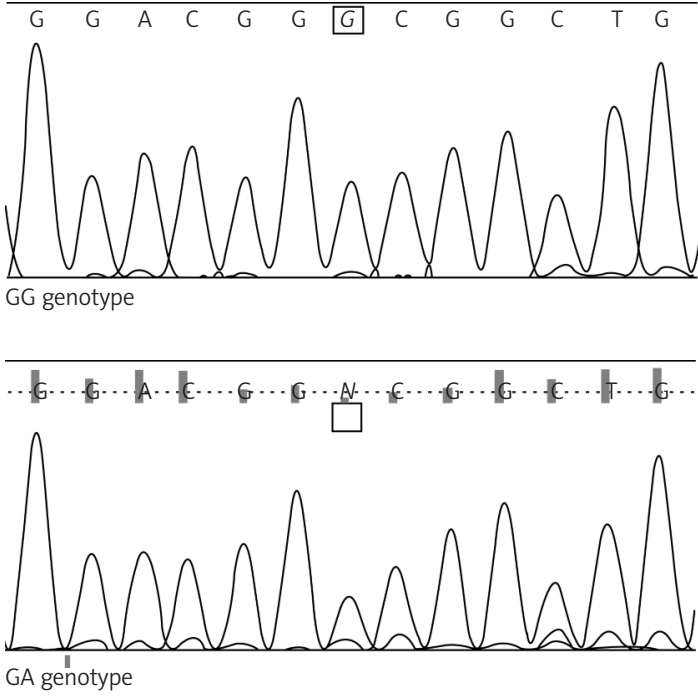

Figure 2. Diagrams of BAX promoter variations in women

in the promoter region. The frequencies of the GG and AG genotypes were $95.52 \%$ and $4.48 \%$ among the RPL group and $81.43 \%$ and $18.57 \%$ among the controls, respectively. This difference was significant $(P=0.01)$. Also, the allele frequencies among the women with RPL and the controls were $2.24 \%$ and $9.29 \%$ for allele A (wild type), and $97.76 \%$ and $90.71 \%$ for allele G (mutant type), respectively. Therefore, an association could be suggested between allele $G$ and the occurrence of RPL. $(P=0.012$, odds ratio $=0.22 ; 0.05<O R<0.87$; Table V).

The substitution of guanine with cytosine ( $\mathrm{G}>\mathrm{C}$ ) at nucleotide 90 in the coding region of exon 1 changes the amino acid glutamine to histidine at codon $7(\mathrm{Q} 7 \mathrm{H})$. This allele alteration was seen in 33 (24.62\%) of the RPL and 11 (7.86\%) of the healthy women $(P=0.0001$, odds ratio $=3.83,1.76<\mathrm{OR}$ $<8.51)$. Also, transition of guanine to adenine (G > A) was seen at nucleotide 95. In this alteration, the amino acid arginine is changed to lysine at location 9 (R9K) in 93 (69.40\%) of the RPL and 20 (14.29\%) of the healthy women $(P<0.0000$, odds ratio $=13.61,7.19<O R<26)$. The genotype and the allele frequency of these genotypes are shown in Tables IV and V.

For exons 2, 3, 4, 5, 6, and 7, however, no nucleotide alterations were seen in the women with RPL.

\section{Discussion}

In this study, Bax gene nucleotide alterations were investigated in RPL women. Also, the association between the polymorphic sites in the promoter as well as the coding regions of the Bax gene and the occurrence of RPL was studied. One polymorphism

Table IV. Genotypes of Bax variations among RPL and healthy women

\begin{tabular}{|c|c|c|c|c|c|}
\hline \multicolumn{3}{|c|}{ Polymorphisms } & \multicolumn{3}{|c|}{ Genotype frequency } \\
\hline & & & Women with RPL $(n=67)^{a}$ & Healthy women $(n=70)^{a}$ & $P$-value ${ }^{b}$ \\
\hline \multirow[t]{2}{*}{$A(-179) G$} & \multirow[t]{2}{*}{ Genotypes } & GG & $64(95.5)$ & $57(81.4)$ & \multirow[t]{2}{*}{0.010} \\
\hline & & $\mathrm{GA}$ & $3(4.5)$ & $13(18.6)$ & \\
\hline \multirow[t]{3}{*}{ G90C } & \multirow[t]{3}{*}{ Genotypes } & CC & $11(16.4)$ & $4(5.7)$ & \multirow[t]{3}{*}{0.005} \\
\hline & & CG & $11(16.4)$ & $3(4.3)$ & \\
\hline & & GG & $45(67.2)$ & $63(90)$ & \\
\hline \multirow[t]{3}{*}{ G95A } & \multirow[t]{3}{*}{ Genotypes } & $A A$ & 39 (58.2) & $6(8.6)$ & \multirow[t]{3}{*}{$<0.001$} \\
\hline & & $A G$ & $15(22.4)$ & 8 (11.4) & \\
\hline & & GG & $13(19.4)$ & $56(80)$ & \\
\hline
\end{tabular}

$R P L-$ Repeated pregnancy loss, a Values in parenthesis are percentages, ${ }^{b}$ Pearson chi square test

Table V. Allele frequencies of Bax variations among RPL and healthy women

\begin{tabular}{|c|c|c|c|c|c|}
\hline \multicolumn{2}{|c|}{ Polymorphisms } & \multirow[b]{2}{*}{$\begin{array}{l}\text { Women with RPL } \\
\text { (134 alleles })^{\mathrm{a}}\end{array}$} & \multicolumn{3}{|c|}{ Allele frequency } \\
\hline & & & $\begin{array}{l}\text { Healthy women } \\
(140 \text { alleles })^{a}\end{array}$ & $P$-value ${ }^{b}$ & $\begin{array}{c}\text { Odds ratio } \\
95 \% \mathrm{Cl}\end{array}$ \\
\hline \multirow[t]{2}{*}{$A(-179) G$} & Allele A & $3(2.24)$ & $13(9.29)$ & 0.0128 & 0.22 \\
\hline & Allele G & 131 (97.76) & $127(90.71)$ & & \\
\hline \multirow[t]{2}{*}{ G90C } & Allele C & $33(24.62)$ & $11(7.86)$ & 0.0001 & 3.83 \\
\hline & Allele G & $101(75.37)$ & $129(92.14)$ & & \\
\hline \multirow[t]{2}{*}{ G95A } & Allele A & $93(69.40)$ & 20 (14.29) & $<0.0001$ & 13.61 \\
\hline & Allele G & $41(30.60)$ & $120(85.71)$ & & \\
\hline
\end{tabular}

$R P L-$ Repeated pregnancy loss, a Values in parenthesis are percentages, ${ }^{b}$ Pearson chi square test, $\mathrm{Cl}$ - confidence interval 
in the promoter region, $\mathrm{A}(-179) \mathrm{G}$, and two mutations in exon 1, G90C and G95A, were identified as novel variations in the Bax gene (Table IV).

There was a significant A(-179)G polymorphism in the promoter region of the patients, which suggests its involvement in spontaneous miscarriages. The G(-248)A promoter polymorphism, which is associated with increased lifespan of neutrophils in osteomyelitis, has been previously reported [27] Also, this variation results in a significantly lower survival rate in patients with chronic lymphocytic leukaemia [28]. Sequence variations in the Bax gene promoter can affect its expression and its proapoptotic function $[24,29]$. It is known that changes in the 5' untranslated region sequence can inhibit the initiation of translation. It can alter the expression of the Bax protein and most likely implicates a post-transcriptional mechanism [30]. Thus, the polymorphism in its promoter region can cause declined expression, activation and ultimately apoptosis. However, according to our data the frequency of promoter polymorphism in RPL women is lower than in control women, which supports this hypothesis. On the other hand, quantitative PCR and Western blot are suggested for future studies to investigate whether the observed mutation in the promoter region really affects the expression of Bax protein in the tissues.

The changes found in exon 1 lead to amino acid alterations and finally changed properties of Bax protein. Based on the bioinformatic analysis, the Q7H and R9K alterations lead to increased final total energy and decreased Bax protein stability (http://swiss-model.expasy.org). These polymorphisms can raise the pro-apoptotic activity of the Bax protein in relation to other proteins or independently. Therefore, an increased tendency of the cell to death or apoptosis will result. This mechanism could underlie the role of these variations in inducing pregnancy loss. However, to support this hypothesis, site-directed mutagenesis and in vitro expression studies are needed to provide more functional data on the role of these mutations.

Apoptosis, or programmed cell death, is responsible for a number of normal developmental processes [31]. Since the regulation of cell death and proliferation is required for successful human pregnancy, apoptosis and its precise regulation are crucial in a normal pregnancy [32, 33]. Therefore, the aberrant expression of apoptosis-related genes during development is also detrimental and can lead to RPL. Interestingly, higher expression levels of apoptosis-related genes, including the Bax gene, were observed in chorionic villi of RPL patients compared to normal people [34]. Bax induces apoptosis, and the ratio of its homo- and heterodimers to $\mathrm{Bc} 22$ determines the fate of the cell [35]. Different constitutive expressions of Bax are related to the $\mathrm{Bc} 12 / \mathrm{Bax}$ ratio, leading to the failure of mitochondrial disruption associated with conformational changes. Dysfunction and dysregulation of the apoptotic programme is involved in some pathological conditions such as cancers, neurodegenerative disorders and autoimmune diseases [36]. Also, apoptosis of villous trophoblasts is upregulated in common pregnancy diseases related to the placenta, intrauterine growth retardation (IUGR), and pre-eclampsia [37, 38].

The Bax gene is also a primary transcriptional target after p53 activation [26, 39, 40]. It is possible that the other role of $A(-179) G$ or $G 90 C$ and G95A polymorphisms is blunting of the cellular response to p53 activation via both transcription-dependent and independent factors. More research is needed to clarify how this proapoptotic effect of Bax polymorphisms may cause susceptibility to RPL.

Because of the difficulties in obtaining aborted materials, in the current study we focused solely on the parents.

Based on the studies conducted so far, more than 40 gene products are differentially expressed in the RPL compared to the normal women. These genes may have regulatory roles in establishing or maintaining normal pregnancy [21]. Therefore, any nucleotide alterations in such genes may lead to different expression and activity which endangers the general health during pregnancy. A better understanding of the genetic background and the physiological significance of these polymorphisms may help to manage subsequent pregnancies and prevent pregnancy complications.

\section{Acknowledgments}

This study was supported in a PhD programme by the National Institute of Genetic Engineering and Biotechnology, Tehran, Iran, and the Research and Clinical Center for Infertility of Shahid Sadughi University of Medical Science, Yazd, Iran.

\section{References}

1. Warburton D, Fraser F. Spontaneous abortion risks in man: data from reproductive histories collected in a medical genetics unit. Am J Hum Genet 1964; 16: 1-25.

2. Wilcox AJ, Weinberg CR, O'Connor JF, et al. Incidence of early loss of pregnancy. N Engl J Med 1988; 319: 189-94.

3. Clifford K, Rai R, Watson H, Regan L. Pregnancy: An informative protocol for the investigation of recurrent miscarriage: preliminary experience of 500 consecutive cases. Hum Reprod 1994; 9: 1328-32.

4. Hatasaka HH. Recurrent miscarriage: epidemiologic factors, definitions, and incidence. Clin Obstet Gynecol 1994; 37: 625-34.

5. Tempfer C, Unfried G, Zeillinger R, Hefler L, Nagele F, Huber JC. Endothelial nitric oxide synthase gene polymorphism in women with idiopathic recurrent miscarriage. Hum Reprod 2001; 16: 1644-7.

6. Pietrowski D, Bettendorf H, Riener EK, et al. Recurrent pregnancy failure is associated with a polymorphism in 
the p53 tumour suppressor gene. Hum Reprod 2005; 20 848-51.

7. Goodman C, Goodman CS, Hur J, Jeyendran RS, Coulam C. The association of Apoprotein E polymorphisms with recurrent pregnancy loss. Am J Reprod Immunol 2009; 61: 34-8.

8. Lee HH, Hong SH, Shin SJ, Ko JJ, Oh D, Kim NK. Association study of vascular endothelial growth factor polymor phisms with the risk of recurrent spontaneous abortion. Fertil Steril 2010; 93: 1244-7.

9. Govindaiah V, Naushad SM, Prabhakara K, Krishna PC, Radha Rama Devi A. Association of parental hyperhomocysteinemia and C677T Methylene tetrahydrofolate reductase (MTHFR) polymorphism with recurrent pregnancy loss. Clin Biochem 2009; 42: 380-6.

10. Topalidou M, Effraimidou S, Farmakiotis D, et al. Low protein $Z$ levels, but not the intron $F$ G79A polymorphism, are associated with unexplained pregnancy loss. Thrombosis Res 2009; 124: 24-7.

11. Rull K, Nagirnaja L, Ulander VM, et al. Chorionic gonadotropin beta-gene variants are associated with recurrent miscarriage in two European populations. J Clin Endocrinol Metab 2008; 93: 4697-706.

12. Sata $F$, Yamada $H$, Yamada A, et al. A polymorphism in the CYP17 gene relates to the risk of recurrent pregnancy loss. Mol Hum Reprod 2003; 9: 725-8.

13. Firouzabadi RD, Ghasemi N, Rozbahani MA, Tabibnejad N. Association of $\mathrm{p} 53$ polymorphism with ICSI/IVF failure and recurrent pregnancy loss. Aust N Z J Obstet Gynaecol 2009; 49: 216-9.

14. Alikani M, Cohen J, Tomkin G, Garrisi GJ, Mack C, Scott RT. Human embryo fragmentation in vitro and its implications for pregnancy and implantation. Fertil Steril 1999; 71: 836-42.

15. Van Blerkom J, Davis P, Alexander S. A microscopic and biochemical study of fragmentation phenotypes in stageappropriate human embryos. Hum Reprod 2001; 16 : 719-29.

16. Jurisicova A, Antenos M, Varmuza S, Tilly JL, Casper RF. Expression of apoptosis-related genes during human preimplantation embryo development: potential roles for the Harakiri gene product and Caspase-3 in blastomere fragmentation. Mol Hum Rep 2003; 9: 133-41.

17. Braude P, Bolton V, Moore S. Human gene expression first occurs between the four- and eight-cell stages of preimplantation development. Nature 1988; 332: 459-61.

18. Yang MY, Rajamahendran R. Expression of Bcl-2 and Bax proteins in relation to quality of bovine oocytes and embryos produced in vitro. Anim Reprod Sci 2002; 70: 159-69.

19. Spanos S, Rice S, Karagiannis P, et al. Caspase activity and expression of cell death genes during development of human preimplantation embryos. Reproduction 2002; 124: 353-63.

20. Kawamura K, Fukuda J, Kodama H, Kumagai J, Kumagai A Tanaka T. Expression of Fas and Fas ligand mRNA in rat and human preimplantation embryos. Mol Hum Reprod 2001; 7: 431-6.

21. Baek KH. Aberrant gene expression associated with recurrent pregnancy loss. Mol Hum Reprod 2004; 10: 291-7.

22. Bellosillo B, Villamor N, Lopez-Guillermo A, et al. Spontaneous and drug-induced apoptosis is mediated by conformational changes of Bax and Bak in B-cell chronic lymphocytic leukemia. Blood 2002; 100: 1810-6.

23. Zhang L, Yu J, Park BH, Kinzler KW, Vogelstein B. Role of BAX in the apoptotic response to anticancer agents. Science 2000; 290: 989-92.
24. Rampino N, Yamamoto $H$, Ionov $Y$, et al. Somatic frameshift mutations in the BAX gene in colon cancers of the microsatellite mutator phenotype. Science 1997; 275: 967-9.

25. Vinothini G, Letchoumy PV, Prathiba D, Nagini S. Immunohistochemical analysis of biomarkers in patients with adenocarcinoma of the breast: correlation with menopausal status and histological grade. Arch Med Sci 2008; 4: 129-39.

26. Miyashita T, Reed JC. Tumor suppressor p53 is a direct transcriptional activator of the human bax gene. Cell 1995; 80: 293-9.

27. Ocana MG, Valle-Garay E, Montes AH, et al. Bax gene $\mathrm{G}(-248) A$ promoter polymorphism is associated with increased lifespan of the neutrophils of patients with osteomyelitis. Genet Med 2007; 9: 249-55.

28. Starczynski J, Pepper C, Pratt G, et al. Common polymorphism $\mathrm{G}(-248) \mathrm{A}$ in the promoter region of the bax gene results in significantly shorter survival in patients with chronic lymphocytic Leukemia once treatment is initiated. J Clin Oncol 2005; 23: 1514-21.

29. Meijerink JP, Mensink EJ, Wang K, et al. Hematopoietic malignancies demonstrate loss-of-function mutations of BAX. Blood 1998; 91: 2991-7.

30. Saxena A, Moshynska O, Sankaran K, Viswanathan S, Sheridan DP. Association of a novel single nucleotide polymorphism, G(-248)A, in the 5'-UTR of BAX gene in chronic lymphocytic leukemia with disease progression and treatment resistance. Cancer Lett 2002; 187: 199-205.

31. Kumagai K, Otsuki Y, Ito Y, Shibata MA, Abe H, Ueki M. Apoptosis in the normal human amnion at term, independent of $\mathrm{Bcl}-2$ regulation and onset of labour. Mol Hum Reprod 2001; 7: 681-9.

32. Chatzaki E, Makrigiannakis A, Margioris AN, Kouimtzoglou E, Gravanis A. The Fas/FasL apoptotic pathway is involved in kappa-opioid-induced apoptosis of human endometrial stromal cells. Mol Hum Reprod 2001; 7: 867-74.

33. Jerzak M, Bischof P. Apoptosis in the first trimester human placenta: the role in maintaining immune privilege at the maternal-foetal interface and in the trophoblast remodelling. Eur J Obstet Gynecol Reprod Biol 2002; 100: 138-42.

34. Choi HK, Choi BC, Lee SH, Kim JW, Cha KY, Baek KH. Expression of angiogenesis- and apoptosis-related genes in chorionic villi derived from recurrent pregnancy loss patients. Mol Rep Develop 2003; 66: 24-31.

35. Wyllie AH. The genetic regulation of apoptosis. Curr Opin Genet Dev 1995; 5: 97-104.

36. Fadeel B, Orrenius S, Zhivotovsky B. Apoptosis in human disease: a new skin for the old ceremony? Biochem Biophys Res Commun 1999; 266: 699-717.

37. Smith SC, Baker PN, Symonds EM. Increased placental apoptosis in intrauterine growth restriction. Am J Obstet Gynecol 1997; 177: 1395-401.

38. Ishihara N, Matsuo H, Murakoshi H, Laoag-Fernandez JB, Samoto T, Maruo T. Increased apoptosis in the syncytiotrophoblast in human term placentas complicated by either preeclampsia or intrauterine growth retardation. Am J Obstet Gynecol 2002; 186: 158-66.

39. Oltvai ZN, Milliman CL, Korsmeyer SJ. BCl-2 heterodimerizes in vivo with a conserved homolog, Bax, that accelerates programmed cell death. Cell 1993; 74: 609-19.

40. Selvakumaran M, Lin HK, Miyashita T, et al. Immediate early up-regulation of bax expression by $\mathrm{p} 53$ but not TGF beta 1: a paradigm for distinct apoptotic pathways. Oncogene 1994; 9: 1791-8. 